\title{
Demographic Problems as Hindrance for Sustainable Development of a Mining Region (the Case of Kemerovo Region)
}

\author{
Elena Morozova ${ }^{1}$,Elena Pastukhova ${ }^{1, *}$, Timur Logunov ${ }^{2}$ \\ ${ }^{1}$ Kemerovo State University, I.P. Povarich Department of Management, 650043 Kemerovo, 6 \\ Krasnaya st., Russian Federation \\ ${ }^{2}$ Kemerovo State University, Department of Foreign Languages in Professional Communication, \\ 650043 Kemerovo, 6 Krasnaya st., Russian Federation
}

\begin{abstract}
Positive dynamics of the general indicators of population reproduction is both the basis and the goal of sustainable development in a region. The analysis shows that the demographic problems of the studied mining region hinder the sustainable development of Kemerovo Region (Kuzbass). These issues include long-term population decline, age and gender imbalances in the structure of the population, an increase in the number of citizens older than the working age, and an increase in the demographic burden on the economically active population. The resource and industrial nature of Kuzbass plays a significant role in the dynamics of these processes. The study examines the relationship between demographic indicators and those of sustainable development. The influence of demographic processes was studied by the method of correlation and regression analysis. The authors found negative impact of the dynamics in the population reproduction processes on the number of people employed in the region's economy, on the gross regional product and investment in fixed assets. A statistically significant relationship was established between mortality rate of the entire population, mortality of the working age group and indicators of sustainable development. The reasons for the high mortality rates in the region include the employment of a significant part of the workforce in hard and hazardous working conditions, high occupational morbidity, injuries, adverse environmental conditions caused by intensive mining, air pollution, and industrial waste. It is concluded that in developing a regional social and economic policy, the positive dynamics of population reproduction processes should be considered as a key factor in the region's sustainable development.
\end{abstract}

\section{Introduction}

World experience shows that sustainable development of regions is impossible without their successful demographic development. The research concept "sustainable development" is

*Corresponding author: peau.13@yandex.ru 
interpreted as harmonization, balanced development of economic, social and environmental subsystems. In this vein, demographic development should be correlated with such priorities as a healthy, long, and socially active life, the possibility of obtaining resources for a decent living standard [1]. Demographic processes determine the condition state of population health. Its level and quality, in turn, shape the gender and age structure of the population, the demographic burden on working age citizens, fertility, mortality, and life expectancy [2-5].

Considered in the framework of sustainable development ideology, the reproduction of the population with its quantitative and qualitative characteristics forms the basis and goal of sustainable development of any region [6].

The study of this issue based on the case of Kuzbass is relevant due to the following demographic problems in the mining region: a long depopulation, an increase in age and gender imbalances in the population structure of the region, an increase in the number of people older than working age, a high mortality rate for men of working age, and significant differences in the life expectancy at birth for men and women. An important role in the dynamics of the above processes is played by the resource and industrial nature of Kuzbass [7].

The negative impact occurs due to a rather low standard of living of a significant population's proportion, the labour under hard and hazardous working conditions, high occupational morbidity and injuries in the coal industry. An adverse environmental situation caused by intensive mining activities results in air and water pollution, dehydration and salinization of the soil, and deformation of the earth's surface [8]. Contaminated air and water, depletion of soil resources have a negative impact on the health of citizens. All of the above factors put together determine the processes of population reproduction. This paper focuses on the analysis of the dynamics of demographic processes and studying of their relationship with sustainable development indicators in the region.

\section{Materials and methods}

The empirical basis of the study includes the official data of the Federal State Statistics Service of the Russian Federation available in the statistical compendiums "Regions of Russia. Socio-economic indicators. 2019", "Demographic Yearbook of Russia. Information by constituent entities of the Russian Federation. 2019", "Healthcare in Russia. Information by constituent entities of the Russian Federation. 2019". To analyze regional demographic issues, the study considers statistical data in dynamics for 2000-2018 including the following indicators: the population of the region, gender and age structure of the population, births per 1000 and total fertility rate, deaths per 1000 (including mortality of the working age group), life expectancy at birth of the entire population and for men and women separately.

The study employed general scientific (comparative analysis, synthesis, comparison, correlation of data) and statistical methods. Correlation and regression analysis was used to identify the relationship of demographic processes and indicators characterizing the sustainable development in the region. Correlation coefficients and regression equations were calculated with the IBM SPSS Statistics Base application package.

\section{Results and discussion}

In Kemerovo Region, long-term population decline is one of the demographic issues of top priority. The main reason for the decline in the region's population is a significant excess of mortality over fertility rates. Between 2000-2018 the population decreased by 279 
thousand people. The population was reducing most intensively in 2000-2008, followed by a recorded decrease in the rate of natural population decline. However, in 2017, the fertility rate began to decline again, while mortality increased, which resulted in the increase in the natural population decline rate. The corresponding statistics are presented in Table 1.

Table 1. Population reproduction rates of Kemerovo Region.

\begin{tabular}{|c|c|c|c|c|}
\hline Years & $\begin{array}{c}\text { Population size, } \\
\text { thousand people }\end{array}$ & $\begin{array}{c}\text { Births per 1000 of } \\
\text { population }\end{array}$ & $\begin{array}{c}\text { Deaths per 1000 } \\
\text { of population }\end{array}$ & $\begin{array}{c}\text { Natural } \\
\text { population decine, } \\
\text { thousand people }\end{array}$ \\
\hline 2000 & 2953 & 9.0 & 16.7 & -7.6 \\
\hline 2002 & 2906 & 10.1 & 17.7 & -7.6 \\
\hline 2004 & 2864 & 10.7 & 18.3 & -7.6 \\
\hline 2006 & 2832 & 11.3 & 17.3 & -6.0 \\
\hline 2008 & 2823 & 13.2 & 16.6 & -3.4 \\
\hline 2009 & 2822 & 13.6 & 16.2 & -2.6 \\
\hline 2010 & 2767 & 13.1 & 16.1 & -3.0 \\
\hline 2011 & 2756 & 12.7 & 15.5 & -2.8 \\
\hline 2012 & 2747 & 13.8 & 15.2 & -1.4 \\
\hline 2013 & 2738 & 13.6 & 14.5 & -0.9 \\
\hline 2014 & 2730 & 13.2 & 14.6 & -1.4 \\
\hline 2015 & 2721 & 12.5 & 14.5 & -2.0 \\
\hline 2016 & 2713 & 12.1 & 14.3 & -2.2 \\
\hline 2017 & 2702 & 10.5 & 14.1 & -3.6 \\
\hline 2018 & 2674 & 9.9 & 14.4 & -4.5 \\
\hline
\end{tabular}

The decline in the region's population had a negative impact on the age and gender structure. The deterioration of the latter is caused by the influence of depopulation processes. Throughout the period in question, the proportion of the population older than working age exceeded the number of young people under 16 . The corresponding indicators are summarized in table 2.

Table 2. Age structure of the population of Kemerovo Region.

\begin{tabular}{|l|c|c|c|c|}
\hline Years & $\begin{array}{c}\text { The proportion of } \\
\text { population } \\
\text { younger than } \\
\text { working age, \% }\end{array}$ & $\begin{array}{c}\text { The proportion of } \\
\text { working age } \\
\text { population, \% }\end{array}$ & $\begin{array}{c}\text { The proportion of } \\
\text { population older } \\
\text { than working age, } \\
\text { \% }\end{array}$ & $\begin{array}{c}\text { Demographic } \\
\text { burden coefficient }\end{array}$ \\
\hline 2000 & 19.3 & 60.9 & 19.8 & 642 \\
\hline 2002 & 18.1 & 62.3 & 19.6 & 618 \\
\hline 2004 & 16.9 & 63.6 & 19.5 & 572 \\
\hline 2006 & 16.3 & 63.9 & 19.8 & 565 \\
\hline 2008 & 16.4 & 63.2 & 20.8 & 581 \\
\hline 2009 & 16.8 & 62.4 & 20.8 & 601 \\
\hline 2010 & 17.3 & 61.0 & 21.7 & 639 \\
\hline 2011 & 17.6 & 60.1 & 22.3 & 662 \\
\hline 2012 & 18.0 & 59.2 & 22.8 & 691 \\
\hline 2013 & 18.5 & 58.1 & 23.4 & 720 \\
\hline 2014 & 18.9 & 57.1 & 24.0 & 750 \\
\hline 2015 & 19.3 & 56.1 & 24.6 & 781 \\
\hline 2016 & 19.5 & 55.4 & 25.1 & 805 \\
\hline 2017 & 19.6 & 54.8 & 25.6 & 827 \\
\hline 2018 & 19.6 & 54.3 & 26.1 & 842 \\
\hline
\end{tabular}

In Kuzbass, the proportion of children and adolescents is less than $20 \%$ of the total population size. For the period between 2000-2018, the proportion of senior citizens 
increased from $19.8 \%$ to $26.1 \%$; the proportion of young people was falling intensively in 2004-2009. In subsequent years, due to increased fertility, the number of children began to increase. However, the ratio of people younger and older than working age remains unfavorable. As a result of this, the demographic burden on the working-age population group is growing mainly due to the high proportion of senior people. Over the past nineteen years, the corresponding indicator has increased from 642 to 842 (by $31 \%$ ).

An important role in the reproduction of the population is played by the optimal ratio of men and women. The increase in gender imbalances has a negative impact on demographic processes in the mining region. In 2000, 1,118 women were recoded per one thousand men in Kuzbass. Until 2014, this ratio had worsened, reaching a value of 1,180 women per 1,000 men. During the following period, some stabilization and a slight increase in the proportion of men were observed. Throughout the analyzed period, the number of women exceeded the number of men by $16-18 \%$ in the region. The main reason for gender imbalances is higher mortality rates for men, especially those of working age [9]. This problem has an adverse impact on life expectancy at birth (LEB) in men, which is significantly lower than that in women.

In 2000, the LEB across the entire population of the region was 62.7 years, including 56.4 years for Kuzbass men and 69.8 years for women (gender differences in LEB amounted to 13.4 years). In 2000-2010, the LEB for region's women was 13.1-13.9 years higher than that for men. Between 2011 and 2018 the differences decreased slightly, but it continues to remain extremely high amounting to 11.2-12.9 years. In 2018, the LEB of the entire population was 69.3 years, 63.7 years for men, and 74.9 years for women (the difference is 11.2 years). The most common causes of male mortality are diseases of the circulatory system, externalities (traffic accidents, suicides, homicide, accidental alcohol poisoning), and neoplastic diseases [10]. Among the leading causes of cardiovascular and oncological diseases is the adverse environmental impact of coal enterprises.

Imbalances in the age and gender structure of the population affect fertility rates negatively. According to demographic estimates, for a mere reproduction of the population, a total fertility rate of $2.11-2.15$ children per woman of reproductive age is required. At best, reaching this value of the indicator can stabilizing the population size in the region. In Kuzbass in 2000-2018, the total fertility rate varied between 1.33 and 1.79 children per woman. The highest value of this rate was recorded in 2013-2014. In subsequent years, the total fertility rate decreased to 1.49 children per woman of reproductive age. The dynamics of these indicators suggests an unfavorable forecast for the sustainable development of the mining region.

A relatively low total fertility rate contributes to further increase in the number and proportion of people older than working age, while reducing the number of working age citizens who are the main part of the workforce. A decrease in the number working age citizens can become a serious hindrance to the economic and social development of Kemerovo Region. Labour shortages, which will not be very noticeable in the near future (due to the COVID-19 pandemic and the subsequent economic crisis), will require future compensation either by means of increasing labour productivity or by the attraction of migrants to Kuzbass from other countries and other Russian regions.

To assess the relationship between demographic situation and sustainable development indicators of the region, a correlation analysis was conducted based on the official statistics for 2000-2018. The following indicators were used to characterize the demographic processes: the population size of the region, births per 1000, the total fertility rate, deaths per 1000, the demographic burden coefficient, and the mortality rate of the working-age group of population. The indicators characterizing the sustainability of the development in the region include the gross regional product (GRP) per one person employed in the economy of the region, fixed investments per one person employed in the economy of the 
region, and the total number of people employed in the economy of the region aged 15-72. The positive dynamics of GRP, fixed investments, and the number of employees indicates the growth of social and economic activity and the creation of favorable conditions for the sustainable development of the region.

Table 3 presents the Pearson correlation coefficients which indicate the presence of an average or significant correlation at a level of $\mathrm{p}<0.05$.

Table 3. The correlation between demographic indicators and indicators characterizing the sustainability of the region's development.

\begin{tabular}{|l|c|c|c|}
\hline \multicolumn{1}{|c|}{$\begin{array}{c}\text { Indicators characterizing } \\
\text { demographic processes }\end{array}$} & $\begin{array}{c}\text { Fixed } \\
\text { investments } \\
\text { per one person } \\
\text { employed in } \\
\text { the economy of } \\
\text { the region, } \mathbf{Y}_{\mathbf{1}}\end{array}$ & $\begin{array}{c}\text { GRP per one } \\
\text { person } \\
\text { employed in the } \\
\text { economy of the } \\
\text { region, } \mathbf{Y}_{\mathbf{2}}\end{array}$ & $\begin{array}{c}\text { Total number of } \\
\text { persons } \\
\text { employed in the } \\
\text { economy of the } \\
\text { region, } \mathbf{Y}_{\mathbf{3}}\end{array}$ \\
\hline Population size of the region, $\mathrm{X}_{1}$ & -0.899 & -0.972 & weak correlation \\
\hline Demographic burden coefficient, $\mathrm{X}_{2}$ & -0.748 & -0.933 & -0.697 \\
\hline Births per 1000 of population, $\mathrm{X}_{3}$ & weak correlation & weak correlation & weak correlation \\
\hline Total fertility rate, $\mathrm{X}_{4}$ & 0.754 & 0.617 & weak correlation \\
\hline Deaths per 1000 of population, $\mathrm{X}_{5}$ & -0.863 & -0.923 & weak correlation \\
\hline $\begin{array}{l}\text { The mortality rate of the working-age } \\
\text { population, } \mathrm{X}_{6}\end{array}$ & -0.841 & -0.946 & -0.542 \\
\hline
\end{tabular}

Almost all analyzed demographic processes (except for births for 1000 and total fertility rate) have a significant negative impact on the indicators of sustainable development. That is, there is an inversely proportional relationship between the number of people employed in the region's economy, the dynamics of the gross regional product, fixed investments per one person employed in the economy, and the indicators of the total population size and mortality including that for the working age group.

To identify the cause-effect relationship between demographic indicators and those of sustainable development, the equations of pairwise linear regression were calculated. Independent variables were demographic indicators $\left(\mathrm{X}_{2}, \mathrm{X}_{4}, \mathrm{X}_{5}, \mathrm{X}_{6}\right)$. Dependent variables included fixed investments $\left(\mathrm{Y}_{1}\right)$, GRP per one person employed in the economy $\left(\mathrm{Y}_{2}\right)$, and the total number of people employed in the economy of the region $\left(\mathrm{Y}_{3}\right)$.

Table 4. Characteristics of linear regression equations describing the influence of demographic indicators on sustainable development indicators of Kuzbass.

\begin{tabular}{|l|c|c|c|}
\hline Characteristics of linear equations & $\begin{array}{c}\text { Fixed } \\
\text { investments } \\
\text { per one person } \\
\text { employed in } \\
\text { the economy of } \\
\text { the region, } \mathbf{Y}_{\mathbf{1}}\end{array}$ & $\begin{array}{c}\text { GRP per one } \\
\text { person } \\
\text { employed in the } \\
\text { economy of the } \\
\text { region, } \mathbf{Y}_{\mathbf{2}}\end{array}$ & $\begin{array}{c}\text { Total number of } \\
\text { persons } \\
\text { employed in the } \\
\text { economy of the } \\
\text { region, } \mathbf{Y}_{\mathbf{3}}\end{array}$ \\
\hline Constant & 0.441 & 2.617 & 1522.2 \\
\hline Demographic burden coefficient, $\mathrm{X}_{2}$ & No linear effect & No linear effect & -1.548 \\
\hline Total mortality rate, $\mathrm{X}_{5}$ & -0.872 & -0.923 & No linear effect \\
\hline $\begin{array}{l}\text { The mortality rate of the working-age } \\
\text { population, } \mathrm{X}_{6}\end{array}$ & -0.861 & -0.946 & No linear effect \\
\hline
\end{tabular}

To assess the significance of the regression equations, determination coefficients were calculated. In all the studied correlations, the corresponding coefficient ranged from 0.761 to 0.897 , which is the optimal indicator for assessing the quality of the equation used. Mortality rates of the entire population (Sig. 0.000) and mortality of working-age group 
(Sig. 0.000) are the most significant factors for decreasing GRP and fixed investments. The demographic burden rate formed mainly due to a high proportion of senior citizens has a significant negative impact on the number of people employed in the region's economy (Sig. 0.002). High mortality rates, including among working age group and an increase in the demographic burden create a serious hindrance to the further economic development of the region.

\section{Conclusion}

The study showed that the state and dynamics of the indicators of population reproduction, its quantitative and qualitative characteristics determine the sustainability of the mining region significantly. The negative dynamics of demographic processes hinders the sustainable development of Kuzbass. The following trends testify to this: long-term natural population decline; a rather low level of life expectancy at birth, especially in Kuzbass men; an intensive increase in the proportion of the senior population and a decrease in the proportion of children and adolescents; growing demographic burden on the working-age population; and imbalances in gender structure.

Statistically significant cause-effect correlations were found between deaths per 1000 of the population, mortality of working-age group, on the one part, and GRP and fixed investments per one person employed in the economy of the region, on the other. The aforementioned demographic indicators contribute to the decrease in GRP and the amount of fixed investments. The demographic burden rate has a significant impact on the reduction in the number of people employed in the economy of the region. These trends increase the burden on the working-age population thus contributing to decline in the economic activity of citizens and to raising expenses for social support and medical care for the elderly.

The population is the bearer of human capital, which is the key component of national wealth. In creating a regional social and economic policy, the positive dynamics of population reproduction processes should be considered a key factor in the sustainable development of the region.

\section{Acknowledgement}

The paper was supported by intrauniversity grant of Kemerovo State University.

\section{References}

1. World Health Rep. 2000: health systems. URL: http://www.who.int/whr/2000/en/index.html

2. R. G. Wilkinson, K. E. Pickett, Soc. Sci. Med., 62, 7 (2006)

3. P. Braveman, L. Gottlieb, Public Health Rep., 29, 2 (2014)

4. A. Boss, V. Kunst, E. Lahelma, M. Bartley, I. Lissau, E. Regidor, Int. J. Epidemiol., 34, 2 (2005)

5. J. W. Lynch., D. G. Smith., G. A. Kaplan., J. S. House, BMJ.m 320, 7243 (2000)

6. P. Braveman, L. Gottlieb, Public Health Rep., 29, 2 (2014)

7. M. Gasanov, S. Zhironkin, EpSBS, VII, 117-123 (2016)

8. V. Zolotukhin, A. Bel'kov, E. Stepantsova, M. Kozyreva, A. Tarasenko, E3S Web Conf., 15, 04015 (2017) 
9. V. M. Shkolnikov, E. M. Andreev, M. McKee, D. A. Leon, Demogr. Res. 28, 32 (2013)

10. E. Pastukhova, E. Morozova, A. Mukhacheva, N. Egorova, CSSDRE Conf., 83, 125909705 (2019) 